\title{
1. What capitalism was
}

Capitalism is the result of a conjunction between laws that deliver individual ownership (property rights) and belief in the value of individuals and their actions. The famous French historian Fernand Braudel devoted three large volumes to it, in which he argued that it has been 'potentially visible since the dawn of history' (1983-1984: 620). It is true that any form of individual control over resources, which implies ownership, will make exchange possible and consequently explains the existence of trade even in prehistoric times. But this is far from the capitalism that made the Western world uniquely rich, by enabling individual human creativity to be directed into economically productive channels on a scale never achieved - or even envisaged - earlier.

Where these two components of capitalism came from will be explored in the next chapter, but the immediate task is to show why they were both essential to it. Taking individualism first, it should be noted that emphasis on this is a comparatively recent development in human history. In his Inventing the Individual: The Origins of Western Liberalism, the political scientist Larry Siedentop describes his story as

How the 'individual' became the organizing social role in the West that is, how the 'civil society' which we take for granted emerged, with its characteristic distinction between public and private spheres, and its emphasis on the role of conscience and choice ... the slow, uneven and difficult steps that have led to individual moral agency being publicly acknowledged, with equality before the law and enforceable 'basic' rights.

(Siedentop 2014: 2)

Individualism does not automatically express itself in social or economic ways. It has often been seen to give priority to survival or literature or art or liturgy. Humans will only take economic activity most seriously if it is linked with individual property. This in turn depends upon the prior existence of some political arrangement for setting the boundaries of a property right and enforcing them, since 
otherwise the strongest will simply take what they want. What we call 'the law of the jungle' is nothing other than absence of laws of property.

Escape from this lack must have begun with forms of 'exclusive communal' rights which, by establishing some form of defence against 'outsiders', prevented the latter from sharing in a resource that a tribe considered to belong to it. The historical shift from hunting and gathering to settled agriculture, about 10,000 years ago, depended on such a development. However, the extent to which such rights can lead to prosperity on their own is quite limited, because of the universal phenomenon of self-interest. Like all other animals, humans are inescapably hardwired to look to their own survival and growth. In what must be the most famous article on economics ever written by a biologist, 'The Tragedy of the Commons', Garrett Hardin used the analogy of a pasture open to all to describe how the pursuit of self-interest in any common property situation causes no problem as long as the limits of the resource have not been reached, but becomes altogether disastrous as soon as they are. This is because:

The rational herdsman concludes that the only sensible course for him to pursue is to add another animal to his herd. And another; and another ... But this is the conclusion reached by each and every rational herdsman sharing a commons. Therein is the tragedy. Each man is locked into a system that compels him to increase his herd without limit in a world that is limited. Ruin is the destination toward which all men rush, each pursuing his own best interest in a society that believes in the freedom of the commons. Freedom in a commons brings ruin to all.

(Hardin 1968: 1244, emphasis added)

Lest it should be thought that Hardin's 'herdsman' example is mere theory, the comparatively recent history of the Newfoundland cod fishery should be considered. This was once the most prolific fishery in the world, but it was a 'commons', as there was free access to it. Consequently, it paid every fishing firm, in its own interest, to invest in the biggest boats and the most advanced gear, until it was completely fished out.

\section{INDIVIDUAL RIGHTS}

The only way out of such disasters is through the generation of individual property rights in the resource, because these can reverse 
the effect of self-interest. Previously this led an individual to act in a way that, when matched similarly by all the other users of a common resource, would destroy it. Once there is individual ownership of the resource it becomes in the interest of each property owner to act so as to preserve his own piece of property intact. The herd-owner in Hardin's example will take care not to expand his herd beyond the grazing capacity of his patch of ground. So will all the other herd-owners, each also acting in their own interest, with the result that the entire resource is preserved. In contrast to what happened in Canada, the authorities in Western Australia made the lobster fishery one of individual property rights, with each fisherman licensed to use a specific number of traps, and the catch monitored in line with reproduction rates. There is no reason why this productive fishery should not go on forever, because it will not be destroyed or even damaged by overfishing.

Of course, there are intermediate situations between the limits of a 'commons' on one side and absolute individual ownership on the other. Swiss farmers have worked out ways of moving their cattle from their individually owned farms to the commonly-owned uplands in summer, and Elinor Ostrom (1990) has recorded the way in which miners in the Yukon set up workable arrangements between themselves before there was any State authority to grant and enforce individual rights. Such cases do not undermine Hardin's basic argument in any way.

Furthermore, and of the highest importance for the generation of wealth, individual ownership makes it in each owner's interest to learn how to use his property to the best advantage. For the first time, there is a link between individual creative energy and investment in generating new economic ideas and information. This learning process makes it possible to increase the output, frequently many-fold, from a resource that would have been destroyed if it had remained a commons. Innovation can become a regular part of economic life. The upshot is that private property rights can 'civilize' self-interest, by constraining it to serve the public good in the process of following its own objectives. What we call 'civil society' can emerge from the social space and opportunity that individual property rights provide (cf. Berger 1993: 6).

Individual property rights can civilize self-interest, but it is not inevitable that they should do so. Instead of submitting to the constraints that 'civilizing' property rights impose, the self-interest of 
individuals, especially when organized into pressure groups, can be directed towards changing the property rights structure to suit themselves. As Douglass North put it:

The rise of impersonal rules and contracts means the rise of the state and with it an unequal distribution of coercive power. This provides the opportunity for individuals with superior coercive power to enforce the rules to their advantage, regardless of their effects on efficiency. That is, rules will be devised and enforced on behalf of the interests of the politically advantaged.

(North 1987: 419)

To the extent that such efforts succeed, they will divert property rights away from serving the public interest towards private interests. Such distorted rights may still have some power to prevent resources from being destroyed, but their ability to underwrite innovation will be lessened. Here is the nub of the historical problem: Our present levels of wealth could not possibly have been reached without vast amounts of innovation, for which efficient property rights in the past were necessary. These rights reflected visions of the public good, and disciplined individual interests towards serving this while following out their own ambitions. In the simplest terms, this meant pointing investors towards technology if they wanted to make money. As will be seen, when the making and preservation of laws of property was captured instead by interests, technological innovation was replaced by innovations in finance which do not serve the real economy.

An inescapable corollary of this is that there is no such thing as the 'free' market. For any market to exist, there must be anterior property rights, and this market will reflect these rights. Those who claim that 'market forces should be allowed to operate freely', are simply arguing for a property right arrangement that happens to suit their own particular interest. There is a connection here with the way in which the laws of any State, the ordinary rules of behaviour that govern and constrain the self-interested actions of individuals, are obeyed. North has pointed out that if enforcement of each and every one of these rules demanded use of the State's power, it would collapse under the weight of the policing costs. States are saved from such collapse by the observable reality that many rules are obeyed voluntarily by individuals even when it would be in their own perceived interest to break them. This happens, North holds, because individuals possess an 'interconnected, comprehensive view' of their 
existence within a larger and at least partly intelligible system. Such a view he calls 'ideology', which he sees as an economizing device that enables the State to dispense with enough policing effort to be able to survive. 'Ideology is inextricably interwoven with moral and ethical judgments about the fairness of the world the individual perceives. . . Strong moral and ethical codes of a society is the cement of social stability which makes an economic system viable' (North 1981: 47).

The set of such codes that made capitalism possible was developed in the seventeenth and eighteenth centuries in Enlightenment philosophy, whose values placed the highest emphasis on the individual and individual action. When this action was directed towards economic development in a context of property rights, it was amazingly productive of wealth, and this was capitalism. The property rights component provided the arena for the activity of a distinctive class of individuals, the bourgeoisie, which was especially capable of turning ideas into concrete realities. It is ironic that the greatest tribute to what this class achieved was written by two of its deadliest enemies, Karl Marx and Frederick Engels, and published in, of all places, the Communist Manifesto of 1848:

The bourgeoisie has been the first to show what Man's activity can bring about. It has accomplished wonders far surpassing Egyptian pyramids, Roman Aqueducts and Gothic cathedrals. .. [and] created more massive and colossal productive forces than all previous generations put together. Subjection of nature's forces to man, application of chemistry to industry and agriculture, steam-navigation, railways, electric telegraphs, cleaning of whole continents for cultivation, canalization of rivers, whole populations conjured out of the ground - what earlier century had even a presentiment that such productive forces slumbered in the lap of social labour?

(Marx and Engels 1950 [1848])

The great economist Joseph Schumpeter had great admiration for Marx's economic diagnosis, if not to the same extent for his prescriptions. Writing to celebrate the centenary of this famous document, he pointed out that the Communist Manifesto contained 'a panegyric upon bourgeois achievement that has no equal in economic literature'. He urged his readers to

Observe, in particular, the emphasis upon the creative role of the business class. Never, I repeat, and in particular by no modern defender of the Bourgeois civilisation, has a brief been composed on behalf of the 
business class from so profound and so wide a comprehension of what its achievement is and what it means to humanity.

(Schumpeter 1949: 209)

\section{DEIRDRE MCCLOSKEY ON CAPITALISM}

What Schumpeter called 'Bourgeois civilisation' is of course capitalism, and a modern scholar who cedes nothing to Marx in her admiration for 'its achievement and what it has meant to humanity' is Deirdre McCloskey. She has quantified it in striking terms: 'Since 1800, the average individual on this planet has been enriched by a factor of 10 and in rich countries by a factor of 30 or more.' She calls this the 'Great Enrichment', and has explained and analysed it in her Bourgeois Virtues (2006), Bourgeois Dignity (2010) and Bourgeois Equality (2016). She prefers to refer to what is generally called 'capitalism' as 'market-tested betterment'. This is because for her the former word 'wrongly suggests that capital accumulation, not innovation, is what made us better off'. She has summarized her main argument in the following way:

The modern world cannot be explained by routine brick-piling, such as the Indian Ocean trade, English banking, the British savings rate, the Atlantic slave trade, the enclosure movement, the exploitation of workers in satanic mills, or the original accumulation of capital in European cities, whether this is physical or human capital. Such routines are too common in world history and too feeble in quantitative oomph to explain the tenor thirty- or one hundred-fold enrichment per person unique to the past two centuries. 'The Great Enrichment,' 1800 to the present, the most surprising secular event in history, is explained instead by 'bettering ideas.'

These ideas, she claims, were turned into concrete realities by what she calls the 'Bourgeois Deal':

Western riches were not made by piling brick upon brick, bachelor's degree upon bachelor's degree, bank balance upon bank balance, but by piling idea upon idea. The bricks, BAs, and bank balances - the capital accumulations - were of course necessary, as was a labor force and the existence of liquid water.

It is the Bourgeois Deal: 'You accord to me, a bourgeois projector, the liberty and dignity to try out my schemes in a voluntary market, and let me keep the profits, if I get any, in the first act - though I accept, reluctantly, that others will compete with me in the second. In exchange, 
in the third act of a new, positive-sum drama, the bourgeois betterment provided by me (and by those pesky, low-quality, price-spoiling competitors) will make you all rich.'

And it did.

To drive home her argument, she uses China as an example:

Chairman Mao's emphasis on class warfare spoiled what gains his Chinese Revolution had achieved. When his heirs shifted in 1978 to 'socialist modernization' they (inadvertently) adopted market-tested betterment, and achieved in thirty years a rise of Chinese per-person real income by a factor of 20 - not a mere 20 percent but 1,900 percent. Deng Xiaoping's anti-equalizing motto was, 'Let some people get rich first.'

In this process, capitalism produced extremes of inequality, which inevitably resulted in calls for redistribution of wealth, but McCloskey claims that this cannot compare with the Bourgeois Deal:

The point is that [redistributions] of 20 or 22 or 25 percent are not of the same order of magnitude as the Great Enrichment, which in turn had nothing in historical fact to do with such redistributions or charitable contributions. The one-time redistributions are two orders of magnitude smaller in helping the poor than the 2,900 percent Enrichment from greater productivity since 1800 . Historically speaking, 2.5 percent is to be compared with a rise in real wages 1800 to the present by a factor of 10 or 30 , which is to say 900 or 2,900 percent. The very poor, in other words, are made a little better off by expropriating the expropriators, or persuading them to give all their money to the poor and follow Me, but much better off by coming to live in a radically more productive economy. If we want to make the non-bosses or the poor better off by a significant amount, 2,900 percent beats a range from 20 to 25 percent every time.

(McCloskey 2014: 106-110)

In Bourgeois Equality, McCloskey dismisses seven 'conventional explanations' that fail to explain the 'Great Enrichment', to unlock its cause. What does explain it, she contends, is ideas. Of course she is right, but wealth only comes from ideas turned into concrete realities, and this in turn requires legal arrangements to tempt people, not just to take risks, but to act under uncertainty. This means individual property rights, but these rights must be of a kind that civilize selfinterest, and not be devised solely or even primarily by those whom they will benefit. 


\section{SCHUMPETER ON CAPITALISM'S HISTORY}

In 1939, Schumpeter published a very large (1,100-page) book, which had as its subtitle $A$ Theoretical, Historical and Statistical Analysis of the Capitalist Process, on the activities so highly praised by Marx and Engels in the Communist Manifesto and by McCloskey today. It was clearly intended to be even bigger, indeed the definitive history of capitalism, but its main title, Business Cycles, limited its scope. Schumpeter had grasped that any economic system based upon property rights does not develop evenly, but through a series of peaks and troughs, a phenomenon for which his pupil, Hyman Minsky, would later provide an explanation in terms of the psychology of investment. While writing this book, Schumpeter was strongly influenced by the work of a Russian scholar, N.D. Kondratieff, on 'The Major Economic Cycles', published in English in 1935. Both works are highly valuable sources for understanding capitalism, not only because of the vast amount of information they contain, but because of how well they can be used to illustrate the ways in which capitalism was shaped by property rights.

Kondratieff assembled indicators from many sources and reported that these showed a regularity in the upswings and downswings of economic activity, with a period of about two generations for each 'cycle'. From his earliest writings, Schumpeter hoped that economics would become a science, and in his search for its unifying theory, Kondratieff's empirical data on long economic cycles looked particularly relevant. There was another reason for Schumpeter to be influenced by Kondratieff. Schumpeter was the first economist to grasp the importance of economic innovation fully, and in fact Business Cycles is a chronicle of innovations. In his Theory of Economic Development, he had observed that innovations do not emerge regularly, but are more in evidence at certain times than at others' (1934 [1911]: 223ff.). Kondratieff's empirical results put flesh on this idea, because he noted that 'innovations tended to "cluster" around the start of "upswings".

It is hardly surprising, therefore, that Schumpeter structured his 1939 book around business cycles. He dealt in extensive detail with three of these, 'the cycle of the industrial revolution, 1780s to 1842'; 'the age of steam and steel, 1842-1897', which he also called the 'bourgeois Kondratieff'; and the cycle of 'electricity, chemicals, motors, 1898-1929'. 
Kondratieff thought of himself primarily as a data-collector, so he had offered no explanation as to why these long economic cycles should exist, nor what caused the 'clustering' he had identified at the start of each of them. In contrast, Schumpeter made clustering into the actual cause of business cycles (1939: 170). He did not try to explain why this should be so, apparently being satisfied by the idea that 'the appearance of one or a few entrepreneurs facilitates the appearance of others' (1934 [1911]: 228). Neither could he show what caused 'clustering' itself, nor did he offer any explanation for the variations in periodicity that Kondratieff had recorded for his long cycles (see Ruttan 1959).

The concept of periodic 'clustering' of innovations, the weight Schumpeter placed on them as the cause of economic upswings, and the absence of an adequate explanation of why either cycles or clustering should exist left him open to criticism. For example, in the American Economic Review assessment of Business Cycles, which Swedberg (1991: 226) called 'devastatingly critical', Simon Kuznets, the originator of the techniques that led to our modern system of National Accounts, went straight for these weaknesses:

\begin{abstract}
What precisely is the necessary connection between scarcity at any given time of high entrepreneurial ability (and the plenitude of imitators) and the bunching of innovations? Given an infinite supply of possible innovations (inventions and other new combinations) why need an entrepreneurial genius defer the next pioneering step until his preceding one has been so imitated and expanded that the upsetting of the equilibrium stops even him in his tracks? If imitators are ready to follow so soon, why should we not conceive these applications of high entrepreneurial ability, whether represented by one man or several, as growing in a continuous stream, a stream magnified in a constant proportion by the efforts of the imitators?
\end{abstract}

(Kuznets 1940: 263)

\title{
SCHUMPETER AND INSTITUTIONS
}

Schumpeter was vulnerable to this and similar criticisms because of his early ambition, already referred to, to develop economics as 'a scientific discipline, distinct in kind from political economy . . . logical and mathematical' (McCraw 2007: 49). As such, it would have to be independent of all exogenous factors. Christopher Freeman (1990: 20-24) called attention to his 'reluctance to conceptualize invention, 
innovation and technology accumulation as a social process'. This made him insensitive to the importance of institutions.

Economics has to have a social dimension, since insofar as it could be a science at all, it would be the science of exchanges. Exchange is only possible if there are property rights, which in turn require a State and legislation for their definition and enforcement. Economics therefore cannot do without the exogenous factors of institutions and laws, but Schumpeter's model left no room for these. In Business Cycles he wrote, for example, that 'It is entirely immaterial whether or not [changes in the institutional framework] are embodied in, or recognized by legislation' (1939: 11). Also, he wrote that money is 'as little a creature of the law than is any other social institution' (cited in Arena and Dangel-Hagnauer, 2002: 7). This of course is true as long as money is gold, silver or the like, but what is known as 'fiat' money, which exists only as paper or on paper, is entirely dependent on the law that makes it legal tender. Ernest Mandel studied long economic cycles from a Marxist perspective (and in fact observed that the Dutch scholar van Gelderen had anticipated Kondratieff in many respects). He found it 'astonishing' that Schumpeter should have overlooked the importance of any institutional change that brings with it the prospect of a steep rise in the rate of profit (Mandel 1975: 137, 145).

\section{INSTITUTIONS AND INTERPRETATIONS OF HISTORY}

Such an attitude to institutions reflects Schumpeter's attraction to the economic interpretation of history, in contrast to Keynes's belief that 'soon or late, it is ideas, not vested interests, that are dangerous for good or evil' (1936: 384). That view implies that institutions have their origin in ideas, but Marx, who is the ultimate founder of the sociology of knowledge, thought the opposite: that ideas and laws were no more than reflections of economic realities on a psychic plane. In the Preface to the Japanese edition of The Theory of Economic Development (1912), Schumpeter had written of his belief in 'a source of energy within the economic system' and that the theory of this system that he was trying to build, was 'exactly the same as the idea and the aim that underlie the system of Karl Marx'. Rosenberg is one of several scholars 
who have discussed this aspect of his thinking (see for illustrations, 1994: 55).

These views of Schumpeter's are from 1911-1912 and they could well have changed by the time he wrote Capitalism, Socialism and Democracy (1997 [1942]), which is certainly less a book of economics than of political economy. This would parallel a reversal of his view about the use of mathematics in economics. Originally, he had bemoaned the lack of this, and in fact was a founder member of the Econometric Society to repair it, but in later life he concluded (possibly helped by the massive amount of research which the writing of Business Cycles needed) that economic and business history were better routes to economic understanding.

\section{ALTERNATIVE VIEW OF LONG CYCLES}

The irony of all this is that institutional changes embodied in legislation were exactly what Schumpeter needed to explain both why business cycles exist, and why innovations 'cluster' at their outset. (They also answer Kuznets's question in his review of Business Studies, why should we not conceive innovations as growing in a continuous stream?). Investment in innovation involves high risk, and a reduction in risk (which equally means higher anticipated profit) can then be expected to bring about increased investment. If a legislative change brings about such a reduction, it is reasonable to expect that a 'cluster' of innovators will then find it possible to obtain the finance they need at much the same time. The true business mind responds with remarkable speed to an opportunity of making money that is opened up by a legal change.

Consider, for example, an investment proposition in Britain in 1854. At that time, apart from shares in entities that owed their origin to specific Royal Charters or Acts of Parliament, such as canals and railways, there was no such thing as limited liability. Every investment in joint stock companies was governed by partnership law, according to which each partner was jointly and severally liable for any debts that might be incurred. If the partnership that brought about the steam power to which we owe so much of the industrial revolution had failed, its creditors would have looked to the rich investor Boulton, rather than to the poor inventor Watt, for recompense. And Boulton's entire fortune without limit could have 
been distrained to pay them. Not surprisingly, the 1854 proposition would have found it very difficult to obtain backing because no rational investor was willing to put his whole fortune at risk in this way. The very same proposition could be highly attractive to investors in 1856, because the Limited Liability Act had been passed in the interim. The most any investor could now lose in the project was whatever small fraction of his fortune he might invest in it, and he could now also spread his risks over a portfolio of several such investments.

Just how revolutionary this legal change was becomes clear when it is recalled that the ability to carry on business without personal responsibility for debts incurred was unknown anywhere until modern times. The nearest the Romans had ever got to it was a device whereby a slave (who did not exist as a person under Roman law) was owned by two or more individuals, who could provide him with money with which to trade on their behalf. The slave's owners could benefit from his trading successes, but were not responsible for his failures (Abatino et al. 2011). Clearly, this could never have led to the development of business on a large scale and it disappeared with the fall of Rome. The legal institution of limited liability is one of the most significant defining characteristics of modern capitalism.

Nothing perhaps illustrates how anaesthetic Schumpeter was to the importance of institutions than his comment that this change in the law of property was just 'another instance of . . . institutional change that merely formulated the logic of an economic situation ... the legislative change itself is of comparatively small importance' (1939: 307). This could have been true of the formal acceptance of usury (the charging of interest for the loan of money) in the sixteenth century, which only came at the end of a long history of devices to circumvent its prohibition. But in the case of limited liability, the change in the law meant an immediate and complete break with the past, and in itself it was of stupendous economic importance.

\section{LENGTH OF ECONOMIC CYCLES}

If institutional change is given its proper importance, the length of a business cycle would then be determined by how long it takes for all potential investors to grasp the implications of such a change, and to take advantage of it. Their entry to a market of course results 
in the competing away of the profits of the originators, leading to the reduced propensity to invest which is characteristic of a cycle's 'downswing', and which eventually brings it to an end. This is the process of 'creative destruction' that Schumpeter himself identified later, in his Capitalism, Socialism and Democracy (1997 [1942]). Moreover, it is also because the changes in the law that get particular 'upswings' going are not equally effective, that cycles vary in length. Economic development consequently reflects the complex interactions between innovations and the laws that both make them economically possible and control their diffusion.

Legal changes that affect property rights, and that change the conditions for investment in doing so, therefore provide a convincing explanation, not only for the existence of economic cycles but also for the clustering of innovations at their start. Envisaged in this way, Schumpeter's first Kondratieff cycle was made possible by the availability of 'full' property rights, the second by general limited liability law and the third by legislation for patent protection, which made corporate investment in research and development attractive.

From such an alternative, institutional perspective, each long cycle is a wave of investment originating in a discrete event, which is a change in the law of property that causes investors' perceptions of future profits to be rendered more optimistic. Of course, behind the actual change in the law there can be an innovation in technology or otherwise that is a stimulus for it. New technologies are not always well accommodated by prevailing institutional structures and require institutional reform if they are to develop effectively. Without a change in patent law in 1952, for example, there would be few if any antibiotics, because valid patents could not be granted for them under the earlier system, and without patents it would not have been rational to invest in research to discover them. Ways of doing business, and not only technologies, may similarly require legal change if they are to develop.

Increased optimism on the part of investors due to a legal change consequently reflects a modification in their perception, first, as to the potential for profit which new circumstances offer, and second, as to the power of related new legislation to enable this potential to be exploited. This results in what Freeman (1990) calls 'a new techno-economic paradigm', or what Nelson and Winter (1982) call a new 'general natural trajectory' (see discussion in Freeman and Louçã 2001: 128, 148). Simultaneous invention is an empirically 
demonstrated phenomenon (Kingston 2004) so it can be reasonably assumed that several individuals will see this potential at the same time and act upon it, resulting in 'clusters' of investment, some of which may result in successful businesses.

\section{A 'MARKET POWER' PARADIGM}

These interactions are most intelligible in the context of what may be called a 'market power' paradigm. The classical economists' meaning of a free market is one with few or no barriers to entry, where prices are under constant downwards pressure. Although this gives consumers lower prices for similar products, it cannot produce innovation, leading to better products. If profits or rents are to be earned to fund the risky investment that innovation requires, there must be means of escaping from a market's freedom of entry condition, and all such means of escape amount to market power.

Paradoxically, market power is therefore not the power to make a market (since this implies freedom of entry) but to unmake it; that is, to find ways of escaping the constraints - especially in terms of price - which market forces seek to impose. Simple concepts of property have been greatly extended so that modern property rights now provide a sophisticated range of such escape means. Nevertheless, these can be grouped under three headings: capability market power, which results from investment in productive assets, the legal underpinning of which is the limited liability legislation which also facilitates multiple investments; persuasive market power, which similarly results from investment in reputation, and depends upon the monopoly in a brand name that trademark registration law gives; and specific market power, where the barrier to entry to a market is provided by the State in the form of an exclusive right, such as a patent. This paradigm is useful in looking at the great amount of historical information in Schumpeter's Business Cycles from an institutional perspective.

\section{FIRST KONDRATIEFF}

What Schumpeter called the first Kondratieff ('the cycle of the industrial revolution, 1780s to 1842') becomes easily intelligible once it is 
seen to be based on legal arrangements that provided for 'full' property rights, which happened first in the Netherlands and England:

$[\mathrm{P}]$ roperty. . . was often hedged around in the pre-industrial period by restrictions on use and disposition and by complications of title. Land especially was caught up in a thicket of conflicting rights of alienation and usufruct, formal and customary, which were a powerful obstacle to productive exploitation. Over time, however, the nations of Western Europe saw an increasing proportion of the national wealth take the form of full property - full in the sense that the various components of ownership were united in the person or persons of the possessor, who could use the object of ownership as he saw fit. Concomitant with this development and, indeed, implicit in it was the growing assurance of security in one's property - an indispensable condition of productive investment and the accumulation of wealth ... [T]he industrial revolution was not the source of modern economic growth. It was the outcome of raising the private rate of return on developing new techniques and applying them to the production process.

(Landes 1969: 23, emphasis added)

Only property rights could 'raise the private rate of return' on investing in doing something new, and they did this by delivering capability market power.

The industrial revolution was primarily about energy. Medieval society in Europe had been the first in history that 'rested not on the backs of sweating slaves, but on non-human power' (White 1968a: 64). But the power of animals and especially of rivers (which the monks of that society were particularly good at exploiting) could not compare in scale with the harnessing of fossil fuel from the eighteenth century onwards. This started in England, not just because that country had massive coal resources, but because it also had the means for exploiting them in James Watt's separate condenser invention, backed by Matthew Boulton's investment. This was what enabled the coal to be extracted by keeping the mines free of water. The coal in turn fuelled more steam engines for large-scale textile manufacture and for the factory system that followed this.

The investment needed to exploit this new energy technology on a wide scale could not have been provided if the mining rights were not secure, which they were because of that long process through which property rights in England had become 'full'. Matthew Boulton was able to back Watt's invention because he was secure in his ownership of a profitable Birmingham button factory. Much of the capital for 
the industrial revolution came from landowners who were equally secure in their property. Some of these became entrepreneurs in their own right, like the Duke of Bridgewater, who built a canal to bring coal from his mines to nearby towns. It has even been plausibly suggested that such people found the risks of investing in technological innovation acceptable, because they were used to betting on their horses (Norway 1954).

This period also saw a great expansion of another institution, the joint stock corporation in which a group of investors could join together for a major project, as in the Hudson's Bay Company, which was formed in 1670 to exploit a grant of two-fifths of modern Canada, and which remains the oldest such firm in the world. The corporation as an entity separate from its members went back to Roman times, although through innovations in thirteenth-century canon (Church) law, it came to be understood as an association of individuals, largely ceasing to have an identity radically independent of and superior to that of its members (Siedentop 2014: 358). It continued vestigially throughout the medieval period, especially in the device of the commendam, a means whereby sea captains could obtain finance for foreign voyages. Eventually, as part of the revival of Roman concepts of law from the seventeenth century onwards, it reverted back to delivering a separation from its owners. The chartered corporations such as the Dutch and British East India Companies, which were given subsequent state monopolies for foreign trade, were all of this type, and they delivered the hugely valuable privilege of limited liability to those who invested in them. The legislation that set these up resulted in very large profits for their shareholders.

Canal-building came next. A canal could not be built without what is known as eminent domain, which is power to interfere with owners' property rights by compulsory purchase of whatever land was needed for its trajectory. Consequently, each joint stock company for a canal required a specific Act of Parliament, and it was not difficult for the promoters to get limited liability included in this, to attract the investment of the large amounts of capital the project would require. The subsequent building of railways was financed in the same way as the canals had been; that is, through corporations with limited liability for shareholders, each of which required its own Act of Parliament. What came to be known in England as the 'manias' for investment in canals and railways were 
caused by perceptions of profits to be made as a direct result of the capability market power that these laws (which of course were laws of property) delivered.

\section{REACTION AGAINST PROPERTY RIGHTS}

What McCloskey (2014: 11) calls 'bettering ideas tested in markets' undoubtedly produced an unprecedented level of economic innovation and wealth, but this brought costs and inequality as well as benefits. Engels's first book, The Condition of the Working Class in England, was based on personal observations and research in Manchester, and revealed the dark side of the new wealth, including child labour and other kinds of deprivation. The praise for the achievements of capitalism in the Communist Manifesto already cited should not blind us to the virulence of the tirade against capitalists in this document. Among the charges laid against them by Marx and Engels (1986 [1848]: 227) was that they had 'pitilessly left no other nexus between man and man than naked self-interest'.

To the extent to which this was justified, property rights were clearly not civilizing self-interest. The same year as the Manifesto (1848) also saw the publication of John Stuart Mill's Principles of Political Economy, which resounds with awareness of this:

The laws of property have never yet conformed to the principles on which the justification of private property rests. They have made property of things which never ought to be property, and absolute property where only a qualified property ought to exist. They have not held the balance fairly between human beings, but have heaped impediments on some, to give advantage to others; they have purposely fostered inequalities and prevented all from starting fair in the race. That all should indeed start on perfectly equal terms, is inconsistent with any law of private property: but if as much pains as has been taken to aggravate the inequality of chances arising from the natural working of the principle, had been taken to temper that inequality by every means not subversive of the principle itself; if the tendency of legislation had been to favour the diffusion, instead of the concentration of wealth, and to encourage the subdivision of the large masses, instead of striving to heap them together; the principle of individual property would have been found to have no necessary communion with the physical and social evils which almost all Socialist writers assume to be inseparable from it.

(Mill 2004 [1848]: Book 1, Chapter 2) 
The lack of an element of social concern in the capitalism of the time explains the violence of the reaction to bourgeois culture that spread throughout Europe during the first half of the nineteenth century. It was particularly expressed in Communism, which declared the class war, identified the proletariat as a party in it, and took its side. Proudhon's dictum that 'property is theft' is a typical expression of the passion that underlay this fierce antagonism to the contemporary rights pattern.

The object of the programme set out in the Communist Manifesto, and of the practical arrangements to put this into effect in the first and second Internationals (Associations of Workingmen) in 1864 and 1889 , was to eliminate private property altogether. Had the Internationals succeeded, capitalism would have ended in violent revolution, but this only happened long afterwards in Russia, where the gap between wealth and poverty was at its widest, and where the more tempered 'European' capitalism had hardly begun to develop.

Capitalism was saved from Communism by an even bigger wave of innovation than the one that was praised in the Communist Manifesto. Marx envisaged that the revolution that would finally put an end to the owners of wealth would be caused by the extreme concentration of ownership. In Capital, he forecast 'the constantly diminishing number of the magnates of capital' as a result of the absorption of weaker firms by stronger ones (Marx 1995 [1889]: Book 1, Chapter xxxii). In fact, there was so much new investment and innovation that the opposite happened. The phenomenon that Schumpeter was later to call 'creative destruction', in which the constant founding of new firms on the basis of new ideas attacked the very lives of existing ones, not alone inhibited the tendency towards monopoly, but massively expanded wealth and employment until World War I. Communism never even got a foothold in the United States, primarily because there was so much innovation and growth in wealth there during the time when the Internationals threatened all property in Europe. America also owed much to Puritanism, which directed so much of this wealth towards philanthropic or public purposes. Andrew Carnegie, for example, who both made great sums of money and gave them away, claimed that 'a rich man who did not die poor was a disgrace' (Carnegie 1889). 


\section{SECOND KONDRATIEFF}

This new wave of innovation, which Schumpeter called 'the age of steam and steel, 1842-1897', or the 'bourgeois Kondratieff', depended upon making the remarkable social innovation of the corporation with limited liability generally available, without the requirement of a Royal Charter or Act of Parliament, such as had been needed for the trading companies, the canals and the railways. This delivered the market power of capability, obtained through investment in productive assets, much more widely. The effectiveness of this type of market power is through scale of operation. If the quality of investment by firms in equipment and personnel is equal, then the one with the biggest investment will have an advantage over the others, because its unit cost of production will be lower. The ability to achieve scale of investment, of course, very largely depends upon the laws that provide for joint stock companies, especially when these can also offer limited liability to their shareholders. Without these, funding would be limited because of the level of risk that individuals and partnerships faced. Neither could the professional management that large businesses require have evolved, since this depended on the separation of management from ownership. It was only limited liability that made this widely possible.

In the United States, the corporate form had been used from colonial times to enable local church congregations to hold property and it was then used for projects such as the Erie canal. Between 1811 and 1848 it evolved to the point where a corporation could be established for any legitimate business purpose (Seavoy 1982). In Britain, for a particular reason that will be discussed below, joint stock companies were illegal from 1720 to 1825 unless they had either a Royal Charter or were the subject of an Act of Parliament. The 1855 Limited Liability Act and the Joint Stock Companies Act of the following year eliminated parliamentary control, so that from then onwards, any corporation established for a money-making purpose (except for dealing in money itself) could offer limited liability to its shareholders.

This piece of legislation to improve property laws was enormously successful: 'Britain went from seven hundred to ten thousand business corporations in twenty years' (North 2010: 219). This development gave British manufacturers such an advantage in reaping economies of scale because of their ease in obtaining capital that 
within a decade this new and extremely valuable property right had been copied throughout Europe.

France was the first to follow Britain in providing for general limited liability, in spite of the fact that the new system involved a degree of business independence of government that was foreign to the French tradition, which is inherently 'centralist'. What happened was that a treaty with Belgium in 1855 included certain provisions for reciprocity, which could be extended to other countries. This was done in respect of Britain in 1862. Once British companies were able to operate in France, local businessmen found that they were at a disadvantage without limited liability, and persuaded their government to pass Acts to introduce this in 1863 and 1867. Spain followed in 1869, and then came Germany in 1870 and Belgium in 1873 (Ripert 1946: 59-62; Landes 1969: 197).

Given the speed and geographical range of its adoption, it would be astounding if this change in the law of property had not caused a new and large-scale economic 'upswing', with the initial cluster of innovations multiplying with the passing of time. By 1895 , for example, British departmental reports showed that there were 18,362 companies on the register, whose paid-up capital was more than three times that of French companies and possibly more than four times those of Germany (cited in McHugh 2000: 112).

\section{THIRD KONDRATIEFF}

This cycle was characterized by Schumpeter as that of 'electricity, chemicals, motors, 1898-1929', or '1898-1938' (see Swedberg 1991: 226 for discussion about the later end-date). It was a cycle of sciencebased industries that needed laws to protect intangible information if they were to develop. Such laws deliver specific market power, meaning power to exclude competition as a result of a particular law or ordinance, where the government is providing the barrier to entry. The first time information as such can be observed to be protected by positive decree is in the grant of rights in it to alpine miners in the Middle Ages. In this case, the information was the whereabouts of a mineral lode, knowledge of which, of course, was highly vulnerable to being spread. This illustrates Nordhaus's (1969: 52) description of information as being 'difficult to produce, easy to reproduce and consequently difficult to profit by'. It was in both a sovereign's inter- 
est and that of the public that individuals should explore for minerals, but why should anyone do this if any success in discovery could benefit others who had done nothing?

Encouragement was consequently provided by the promise of exclusive sharing of the rewards from finds with the sovereign over a term of years. These grants were made in the form of documents open to all to read, that is, 'patent', so this came to be the word used to describe all grants of exclusive rights for a period of time in return for generating economically useful information. It was only comparatively recently that such rights, together with those of trademark registration, copyright and designs, began to be discussed together as a package called intellectual property.

This general principle (of a right in exchange for an expectation of performance) then received explicit legal expression in the Venetian Patent Ordinance of 1474. The primary motivating force for this is clearly a vision of the public good, expressed in this document as: 'We already benefit from the numbers of clever and ingenious people in our city, and we could benefit still more by persuading other people like them to come here also, by offering them the exclusive right to put their new ideas into effect.'

\section{'NEW MANUFACTURE WITHIN THIS REALM'}

A variant of this approach was followed in England, France, some German kingdoms and the Hapsburg realms, and is illustrated in the English Statute of Monopolies of 1623. Successive monarchs had been granting large numbers of privileges to their favourites, one of which, for example, delivered a monopoly over salt and another over making playing cards. The purpose of the 1623 Act was to put an end to these abuses of royal power. It was accepted that there remained a single type of monopoly that was in the public interest, the one that encouraged the introduction of new technology to the country. For this reason, the Act specifically allowed the grant of the privilege of 'the sole working or making of any manner of new manufacture within the realm, to the true and first inventor of such manufacture'.

In this context, the word 'inventor' did not mean someone who thought up a way of 'new manufacture'. Instead, it was the person who found new technology abroad (most likely in Italy, whose cities 
were by far the most advanced in this respect at the time), introduced it to England, and set it up there. The protection offered for doing this lasted for two terms of apprenticeship, or 14 years, as it was considered that this length of time would be needed to get the new technology established.

The information protected by this means was consequently embodied in whatever technology had been found abroad and imported - it was an invention done, that is, its innovation. Only gradually, as can be seen in the evolution of the English law during the eighteenth century, did patents come to be granted for information as such the invention taught. From 1713 in England, for example, it became progressively necessary to be able to write down a description of the invention for which protection was being claimed. This changed the subject matter of patents to 'disembodied' information, and it also reflected the start of replacement of imported technology by indigenous invention as the subject matter for protection. Patents for invention replaced patents for innovation.

\section{PROTECTION OF INFORMATION IN THE UNITED STATES}

Because the Enlightenment philosophy from which capitalism emerged found its highest values in individual human lives and behaviour, it contained radical ideas about individual rights. These values dominated the original settlements in North America, and they also shaped the drafting of the United States Constitution. This reflected a vision of the public good held strongly in common by an exceptional group of people, since generally referred to as the Constitution's 'Framers'. They were well aware of the danger of conflict between the public good and interests in drafting laws and getting them passed. Indeed, their great fear was lest the federal arrangement they had in mind for cooperation between the States might be captured by what they called 'faction', meaning special interest groups. This is why they were so concerned, as Thomas Jefferson put it, "that the powers of government . . . be so divided and balanced among several bodies of magistracy, as that no one could transcend their legal limits, without being effectively checked and restrained by the others' (see Ford 1955 [1781]: 103).

The Framers were careful to leave all legislation on full property 
to the individual states, but the Constitution they shaped is unique in the world in containing an explicit provision to protect information. This provides for quasi-property rights, meaning that they do not last forever, as full property rights do. According to the then prevailing values of the Enlightenment, what authors, artists and inventors do is an extension of their personalities, so that in some sense it is also 'them', or at least 'theirs'. This led naturally to the view that just as the State has a duty to protect the physical life of its citizens, it should also protect extensions of this life in the form of 'the creations of their minds'. It was therefore proposed that 'In order to promote the progress of Science and Useful Arts', the Constitution should allow Congress to pass laws to protect these creations for limited periods.

One of the best-known 'Framers', Thomas Jefferson, was aware of the danger of interests capturing the making of laws, especially laws that related to property. He therefore argued against the proposed article on the ground that 'the benefit of even limited monopolies is too doubtful to be opposed to that of their general suppression' (Ford 1905). However, against the background of some initiatives concerning patents as well as copyright that had been taken earlier by some of the States, his view was not supported. Also, he was absent because he was representing the Union in France when Article 1.8.8 was nodded through the Constitutional Convention. Incidentally, he later changed his mind about this kind of protection, through his experience as Secretary of State of having to operate the Patent Act. This had been passed, together with a Copyright Act, in 1790, within a year of adoption of the Constitution. In 1791, the French Assembly also passed a Patent Act that reflected similar values concerning human creative activity.

Later, Abraham Lincoln was to praise patents for individual inventors as being just as important to the human race as the inventions of writing and of printing, because they 'added the fuel of interest to the fire of genius' (Noble 1977: 84). They made it more rational for investments to be made in new ideas, by delivering specific market power.

However, once inventions became primarily the result of purposive research and development, the US 1790 law no longer worked. The Constitution only empowered Congress to legislate to protect 'for limited times the creations of the minds of individuals'. This meant that if someone was employed to do research, and this resulted in a patentable invention, the patent would be granted to him, not 
his employer. Obviously, it would not be rational to invest in corporate research and development on this basis, but because of the Constitutional restriction, the problem could not be solved within the patent law. Instead, it was solved through employment law. This came about through a Supreme Court decision to the effect that a contract of employment could validly include a clause providing for any patents that might be granted to an individual as a result of his employment to be assigned to his employer (US v. Burns, 1871). Without this change in the effective law, the research and development of in-house research laboratories and workshops, such as Thomas Edison's at Menlo Park, and subsequently in all advanced firms, would not have been possible.

\section{PATENTS IN EUROPE}

The same need as in the USA for patents to be owned by the employers of researchers also existed in Europe, but could only be introduced there by specific legislation. Legal change that can be brought about through judicial ruling in Common Law regimes (mainly the English-speaking countries) may require an actual modification in a statute (or even a new one) in Civil Law jurisdictions, such as those of the European mainland. In respect of information, this began with the German 1877 Patent Act, which Werner Siemens actually went into politics to have passed. The Siemens brothers' firm was ideally positioned to exploit the emerging electrical industries because it already manufactured telegraph cables, in England as well as Germany. Siemens saw, however, that exploiting electricity would need large numbers of employed inventors in company research laboratories. This only made sense if any resulting patents would belong to their employing firm, and not to the individuals (Heggen 1975: 115-118).

This legislation was also of enormous benefit to the German chemical industries, which had pioneered in-house research laboratories since the $1850 \mathrm{~s}$. For example, the first synthetic dye was invented and innovated by Perkin in England in 1857. Although Britain by then had by far the world's largest textile industry to use such dyes, and unlimited supplies of the coal tar used to make them, by the end of the century it was German firms that which dominated the world market for dyes (Murmann 2003: 38-40). 
This dominance depended on their use of patents. So important were these to German industry that when it had to cope with freeriding on its discoveries by firms in Switzerland, it financed three referenda in that country until it got a patent law passed there. It is hard to imagine a better illustration of legislation for property rights as a crucial component of economically important change. German chemical firms were outstandingly successful at building up dominant positions in world markets (Liebenau 1988: Chapter 8). During the first years of the twentieth century, no less than 75 per cent of all dyestuffs patents in Britain and 79 per cent in the USA were held by German firms (Murmann 2003).

The development of patent laws that gave effective protection to inventions resulting from large-scale research and development work in company in-house research laboratories, is consequently perfectly capable of explaining the origin and development of Schumpeter's third Kondratieff cycle. There is little need to look beyond this particular institutional change for anything else in the prodigious growth of the industries dealing with 'electricity, chemicals and motors'.

\section{EXTENDING THE 'LONG WAVE' ANALYSIS - A FOURTH CYCLE?}

Looking at macroeconomic fluctuations in terms of institutional change embodied in legislation makes it possible to extend the analysis of business cycles that Schumpeter started, to obtain further insights into the nature of capitalism, beyond his own three long 'waves'.

The obvious institutional basis of a fourth 'cycle' is the combination of laws that made possible the industries that are based upon brands; that is, those of mass-market consumer goods. Although the fastest growth of the markets for these was a phenomenon of the post-World War II period, the legal changes that made them possible were much earlier. The first of these laws was that of trademark registration, through which brands can become worldwide legal monopolies, and it was an enormous improvement on the protection of reputation provided under Common Law. This had required proof in court from members of the public that they identified a mark on a product as clearly indicating its source, and this proof 
was expensive to search for and almost impossible to obtain. Worse, even if a judgment could be obtained against one copier, there were invariably others to be pursued, so that many firms abandoned litigation as means of protecting their reputations. In contrast, once a national trademark register was in place, this settled the question of ownership of a brand once and for all, and made copying a dangerous business.

To illustrate this, the history of Unilever contains a revealing account of how W.H. Lever grasped what the passage of the 1883 Trademark Registration Act in Britain was going to mean for his business:

Lever, though not technically expert in soap making, had the firm intention of establishing a soap of distinctive quality. The more successful it was, the greater the risk that others would try to copy his trade-mark. A distinctive trade-mark was as important as a distinctive soap ... 'When ["Sunlight"] occurred to me, I had to go straight off to Liverpool and ask Thompson to register it at once: I was all in a tremble to have it registered, for fear somebody else had got it.' Lever's intuition did not mislead him. He had stumbled on a name that could not only be registered in England but in every country in the world.

(Wilson 1954: 27)

Lever was therefore the first member of a 'cluster' that was the vanguard of a flood of investors who grasped that this new legislation had fundamentally changed the way in which business is done, by providing them with a secure property right in reputation. The future would depend upon marketing and advertising to develop this in ways that had never been known before.

The persuasive market power that results from investment in psychological assets ('reputation') is achieved through developing brands like Lever's 'Sunlight'. These are granted true monopoly status by trademark registration law, and their advertising is protected by copyright law. These extremely strong property rights allow massive investment to be made in marketing, to build up knowledge of, interest in and preference for branded products to levels where only a few oligopolistic firms will survive in any product market.

An illustration of the economic importance of brands today is that when a large firm in a branded goods industry is taken over, the price paid is typically a multiple of its book value. Auditors are not allowed to take account of the value as assets of 'home-grown' 
brands, only those for which some objective financial measure exists because they have been bought from outside. The difference between a firm's real and book valuations is the worth of its intangible assets, above all its brands, with its market power resulting from the legal monopoly of their associated registered trademarks. When Nestlé bought Rowntree's, for example, the book value of the firm was $£ 0.4$ billion, the stock exchange value (number of shares in issue multiplied by the share price) was $£ 1$ billion, but Nestlé paid $£ 4$ billion, showing how much the Rowntree's brands were worth to it.

Nor is it by any means only the industries that are characterized by branded products, particularly those of fast-moving consumer goods, which depend largely for their existence on trademark registration law. The range of services that support these products, such as advertising and market research, amount to large industries in themselves. These would simply collapse if there were no brands in the modern sense; that is, those that depend upon having a legally granted trademark monopoly. Today, too, the media obtain most of their revenue from advertising, and professional sport is so largely financed by sponsorship that it also would be impossible without the advertising value it can offer to brands. Franchised businesses, from hotels to hamburgers, depend completely on the simple piece of positive law that delivers trademark registration. For them, it is essential that ownership of a brand can be legally separate from ownership of the associated physical assets. It is even possible to credit quite a proportion of the modern haulage industry's existence to the same property right, since its cargoes are often close to being identical at the physical level, but differences in the public perceptions of brand names still make the goods worth moving, often over very long distances.

\section{AND A FIFTH?}

Among the remarkable social innovations associated with the 19391945 war, one of outstanding importance was the application of science to aspects of manufacturing industry in ways that had never been done before (Kash 1989). The United States government made industrial innovation for the war effort commonplace, by taking the financial risk out of it through subsidies for research and development. The importance of the resulting innovations ranged from the 
antibiotic revolution, which began with the massive investment in penicillin (second only in scale to that in the atomic bomb) made directly by the United States government, to the magnetron, which at one level is the heart of radar and, at a much more trivial one, of the microwave cooker.

As well as new industries developed from wartime research, those of entertainment and information technology could be regarded as characteristic of a fifth 'cycle', and these too can be seen to depend upon legal changes. The modern entertainment industry depends completely on copyright law, and in particular on an enormous lengthening of the period of protection it provides. In the first US Copyright Act of 1790, it was granted to an individual only, and lasted for 14 years, with a further 14 years if the grantee was still alive at the end of the first period. Today, copyright protection is also available to firms, for which the term is 120 years, so that as well as individual creativity it also underwrites all kinds of commercial publishing and not just film and television production, but also cinemas and theme parks.

Investment in information technology on the scale there has been in recent decades was only possible through the availability of copyright to protect computer programs, and later, in the United States (though not in Europe), by giving these programs patent protection also. Indeed it could be argued that the explosive growth of the information technology industries, which originated in the electronic computers invented for wartime code-breaking, justifies being characterized as a cycle on its own, because it led to what was known as the 'dot-com boom'.

Independently, in his Postcapitalism, Paul Mason also details five long cycles, and notes that the fifth one, also driven by 'network technology, mobile communications, a truly global marketplace and information goods' has stalled: 'And the reason it has stalled has something to do with neoliberalism and something to do with the technology itself' (2015: 48). He is right in both, since neoliberalism is best defined as acceptance of the rightness of the existing system of property rights, and, as will be seen, this favours financial innovation at the expense of the technologies that could help to solve the world's pressing problems. 


\section{GLOBALIZATION}

The achievements of capitalism that Marx admired, and the surge of innovation that went on to thwart his dream that it would be replaced by Communism, were all due to the initiatives of individuals operating under national property laws, but during the twentieth century, and particularly after World War II, the focus of capitalists became progressively global. This is particularly the case for Schumpeter's third Kondratieff cycle and for the two later cycles suggested above.

Globalization is not at all the same thing as international trade. This trade began with the chartered companies, such as the Dutch or British East India Companies, which European governments found to be a useful way of funding public debt. The promoters of these found it worthwhile to pay handsomely for a Charter that gave them highly profitable monopoly rights to trade with a particular foreign colony or country. Globalization only began when firms started to obtain property rights outside their own country to protect investments abroad.

For firms whose market power was mainly persuasive and/or specific rather than dependent upon their capability, it was the Paris Convention of 1883 for patents and trademarks, and the Berne Convention of 1886 for copyright that internationalized these property rights. The feature in both Conventions that delivered these rights was 'national treatment'. Each Convention member country could have any information protection arrangements it liked, or none at all, but agreed on joining that it would treat citizens and firms from other member countries just as if they were its own. W.H. Lever used the provisions of the Paris Convention instantly to register his 'Sunlight' soap trademark in the United States and other countries. Almost as soon, Coca-Cola began to sell under its brand in Europe. Germany joined the Paris Convention in 1903, and its chemical firms used its provisions to great advantage in obtaining patents in the US and Britain on their way towards dominating international markets up to World War I. These patents were then sequestrated by bodies such as the Comptrollers of Enemy Property in Britain and the US, where they eventually helped local pharmaceutical industries to develop.

In the case of firms whose characteristic market power was capability, global operation was slower to come about. One reason was 
that the interwar period saw a great upsurge in protectionism in the Depression years after the 1929 Wall Street Crash. However, there were important exceptions. Lever Brothers became one of the first multinational firms by having three manufacturing plants in the US before 1900, and by setting up the United Africa Company to source raw materials there. Another British firm, Liebig's Extract of Meat, invested heavily in meat production throughout South America, and in the other direction, Henry Ford set up a plant in Ireland that was intended to make his tractors for the whole of Europe.

After World War II, many American firms which were skilled in advertising and marketing, turned their attention to foreign markets. Typical of these was Procter \& Gamble, which held the largest share of the detergent and similar markets in the US. With the exception of the purchase of a small soap business in the north-east of England in the interwar period, it had been content to leave the rest of the world to Unilever. After World War II, however, it set up an international division in Geneva, with the intention of capturing a major share of all the world's detergent markets, in which it was very successful.

The American firms that emerged from World War II with unrivalled productive capability, naturally wanted access to worldwide markets for this. To prevent any revival of the worldwide protectionism that had been characteristic of the pre-war era, the United States government took an initiative within the newlyestablished United Nations, which eventually brought about the General Agreement on Tariffs and Trade (GATT) in 1947. Its primary objective was to eliminate tariffs and import quotas, thus globalizing the market power of capability in the same way as the Conventions had earlier globalized specific and persuasive market power. The difference was that the Conventions were Europe-driven in origin and allowed countries to make their own rules. They reflect 'gentleman's agreements', with no compulsion to join, no commonly agreed minimum level of intellectual property protection, and no effective sanctions for breach. In contrast, the GATT was US-driven, focused on achieving worldwide free trade in manufactured products, with dispute resolution means and strong sanctions against offenders.

The GATT's primary objective of dealing with protectionism was triumphantly achieved. In its first 'round', in 1947, it dealt with 23 countries and freed up trade worth $\$ 10$ million; in the 'Kennedy round', in 1962, it did the same for 48 countries and $\$ 40$ billion; 
and in the 1973 'Tokyo round', the totals were 99 countries and $\$ 155$ billion. The putative fourth and fifth economic 'cycles' are closely associated with globalization, reflecting a thrust towards establishment of similar laws of property throughout the world. The World Trade Organization was established to be the main instrument for this, and includes a Trade-Related Intellectual Property Section (TRIPs). This highly significant institutional change came about through agreement at Marrakesh in 1994 on a common public international law (see Sell 2003).

\section{THE MOVE AWAY FROM TECHNOLOGICAL INNOVATION}

It is of course only coincidence that Schumpeter dated the end of the last of his three economic cycles as 1929, but this was also the year of the Great Crash, which was undoubtedly a watershed in economic history. It had profound implications for capitalism, and indeed during the Depression years that followed, it looked as if this was facing its end for a second time.

In the broadest terms, capitalism was primarily about technology until the Great War of 1914-1918, after which the emphasis moved in the direction of financial innovation, although this did not become dominant until the 1990s. Four factors that also became progressively more important during the same period were what may be called the derived market power of workers; social welfare; the widening of the electoral franchise; and public expenditures that responded to voters' pressures.

As far back as the medieval guilds, and in legislation from the early seventeenth century in England, workers were legally forbidden to combine to put pressure on their employers to share their profits with them. Owners also had rights that went back centuries, to pay their workers in tokens that had to be spent in their own shop at inflated prices. These rights were gradually extinguished, and in 1824 in England, the first legislation that led to full power for trade unions was enacted, with workers having to be paid in coin of the realm beginning in 1831 . Just how big a shift this eventually led to in the balance between capital and labour can be seen in the history of Guinness, a large employer and one with a reputation of being in the lead of industrial relations improvements. Figures from Lynch and 


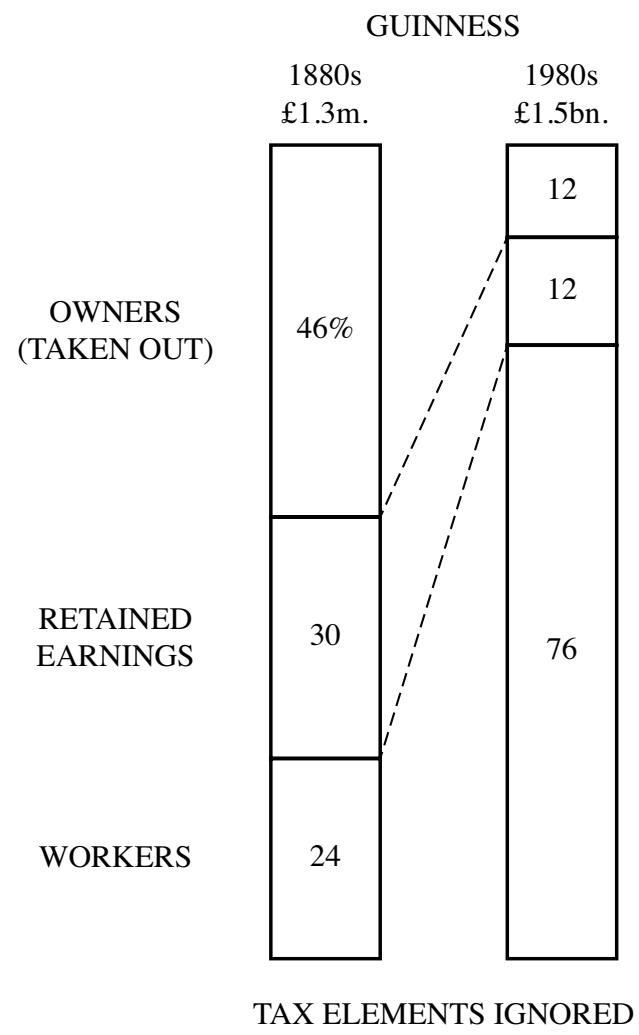

Figure 1.1 The changed balance between owners and workers in the twentieth century (based on Lynch and Vaizey 1960 and Guinness Annual Reports)

Vaizey (1960) for the 1870s and from company reports for a century later show that the balance of the distribution of the firm's after-tax revenue was substantially reversed over the period. If the figures had included corporate taxation, much of which is redistributed as social welfare payments, the contrast would be even more dramatic (see Figure 1.1).

These changes led to mass markets, because they gave wageearners discretionary income to enable them to buy branded and advertised products, so that innovations in marketing became a better way of making money than innovations in technology. The 
amount of this discretionary income was greatly increased by the introduction of social welfare. The first legislation for this was in Germany when Bismarck was Chancellor, and it came to Britain in 1910 in the form of Lloyd George's National Insurance Act.

In the countries that had been involved in the Great War (except for the United States, which entered it late and whose homeland was untouched), the decade afterwards was one of reconstruction rather than innovation, and then came the Depression. In his General Theory of Employment, Interest and Money, published in 1936, Keynes diagnosed the cause of this as unwillingness on the part of those who had capital, to invest it in anything at all (not to speak of risking it in technological innovation). He argued that if private investment failed to deal with unemployment, public investment should replace it, even if this had to go so far as putting people to work digging holes and filling them up again. His thinking was very important in the growth of socialist parties, State intervention and even in President Roosevelt's 'New Deal' in the United States. It also fitted in well with extension of the franchise, so that public expenditure progressively reflected a response to pressures from voters.

This great increase in the availability of public contracts inevitably turned the attention of those who otherwise might have been involved in technological innovation towards ways of making money from these instead. Intervention is, of course, in the interest of civil servants since it expands their domain and provides opportunities for promotion, and even before the General Theory became essential reading for economists, it had been eagerly accepted as the Good News by bureaucrats all over the world. An interesting pointer to the speed of their recognition of the value of Keynes's ideas for them is found in France. There, a mimeograph translation of his book in French was circulating in the Finance Ministry within a year of its original appearance in England, although it was not officially published there for several years afterwards.

\section{TECHNOLOGY SLOWDOWN}

After World War I, and especially after the Great Depression, the pace of technological innovation was clearly slowing down. France, which had led the internal combustion revolution in Europe (every British warplane until 1916 had a French-made engine, for example) 
lacked industrial leadership because of war casualties. It was the same in Britain, where losses of officers on the Western Front had been six times those of men. This imbalance was particular damaging to the civil service and the banks, whose staffs were disproportionately represented in the losses. Those who replaced them after the war were of a different calibre, and they had to work in environments that were not conducive to innovation. This can be illustrated by the development of jet propulsion for aircraft. The steam turbine had been one of the greatest inventions and innovations of the later nineteenth century, and quickly became the standard means of both ship propulsion and electricity generation. It had been the work of Charles Parsons, and during the war he was sent for by Admiral Fisher, then head of the Board of Invention. Fisher explained that German submarines were able to identify the position of ships from the cloud of smoke above them from their coal-burning boilers, and asked could Parsons not 'marry the turbine principle with the internal combustion principle?' Parsons's written response was that not alone could he not do it, but that it was intrinsically impossible (Appleyard 1933: 174).

Yet this was exactly what Frank Whittle achieved when he invented and patented the jet engine in 1930, only fourteen years later. As a serving officer in the Royal Air Force, he had to abandon the patent in 1934 because he could not afford the renewal fee. There was no government support for jet engine development until the late 1930s, when the small Bank which had provided some funding to him was bought out at a price which gave it no compensation for the risk it had taken, and it was in fact a German aircraft which was the first to fly with his invention. During that period, there was massive public funding to develop radar, which was merely a defensive weapon. It is not fanciful that if jet propulsion had received large-scale support in Britain from the outset, the possession of it could have been a deterrent comparable to that provided by the atomic bomb in the post-war period.

\section{CAPITALISM'S 'INDIAN SUMMER'}

In the United States, the economic effects of the Great Crash of 1929 were so devastating that during the Depression years, capitalism looked as if it could come to an end, and there is little doubt that this time it was saved by World War II. Robert Gordon, whose massive 
book The Rise and Fall of American Growth reports in comprehensive detail on the US standard of living since the mid-nineteenth century, claims without reservation that this is the clear import of the evidence:

[The War] represented an economic miracle that rescued the American economy from the secular stagnation of the late 1930s. In fact, the case is overwhelming for the 'economic rescue' interpretation that World War II, along every conceivable dimension, from education and the GI Bill to the deficit-financed mountain of household saving that gave a new middle class the ability to purchase the consumer durables made possible by the Second Industrial Revolution.

(Gordon 2016: 537)

The process whereby the United States government had brought business and science together in a way that had never been done before, effectively taking the financial risk out of work on any potential innovation that could possibly contribute to victory, has been studied in depth by Don Kash, who concluded that:

In the three decades following World War II, the United States dominated commercial innovation using spinoffs of defense innovations which were developed to serve the domestic market ... Although the initial objectives were of course military, the information generated became the basis of entire new industries after the war, apart from delivering equally valuable incremental improvements in already existing products and in their methods of manufacture.

(Kash 1989: 14)

American Research and Development Co., founded in Boston in 1946 by General Doriot to exploit these new technologies, was the start of the modern venture capital industry, which became particularly important in the later 'dot-com boom'.

\section{LESS GROWTH, MORE INEQUALITY}

Once that burst of innovation had been exhausted, however, Gordon's comprehensive data shows only decline, with United States long-term growth 'slowing to a crawl':

Just as 1970 was a watershed, the dividing point between rapid and slow growth in total factor productivity, so there was a parallel and independent 
transition between equal growth for all before 1970 and unequal growth after 1970. By several measures, including median real wages and real taxable income in the bottom 90 per cent of the income distribution, there has been no growth at all. Other measures of income growth below the top 1 per cent show positive rather than zero growth, but at a rate that is substantially slower than averages that include the top 1 per cent. Steadily rising inequality over the last four decades is just one of the head winds blowing at gale force to slow the American standard of living.

(Gordon 2016: 605)

It can hardly be just coincidence that it was so close to Gordon's 'watershed', in 1971, that the last link between fiat (paper or on-paper) money and gold was broken. The gold standard had limited the activity of money creation until the outbreak of World War I, but Britain's attempt to return to it after that war foundered on the use of an exchange rate that did not take account of the damage that had been done to the country's ability to produce and, above all, to innovate, in the interim. After the end of World War II, the Bretton Woods agreement made the United States dollar the world's reserve currency by pegging it to gold at $\$ 35$ an ounce. Other countries were also committed to peg their currencies to the dollar, but flagrantly failed to do so. As this behaviour was to the disadvantage of the United States, the peg of the dollar to gold was abandoned in 1971. From then on all currencies were 'free floating', and 'the global banking system was effectively creating money out of nothing' (Mason 2015: 89). Not only is this within a year of the end of Gordon's 'special century of capitalism', it is within five of the year 1966, identified by Hyman Minsky as the transition of the USA from being a financially robust economy to a financially fragile one (1982: xii.).

Clearly, therefore, those few years identify a fundamental shift in the focus for Western creative energy. Earlier, this had been on technological innovation, but now much of it turned to financial innovation instead (see Goetzmann and Rouwenhorst 2005). This was enabled by institutional changes which will be the subject of Chapter 4.

\section{EMPIRICAL EVIDENCE}

The scale of this change is clearly illustrated by data from the National Bureau of Economic Research in the US on the relative 


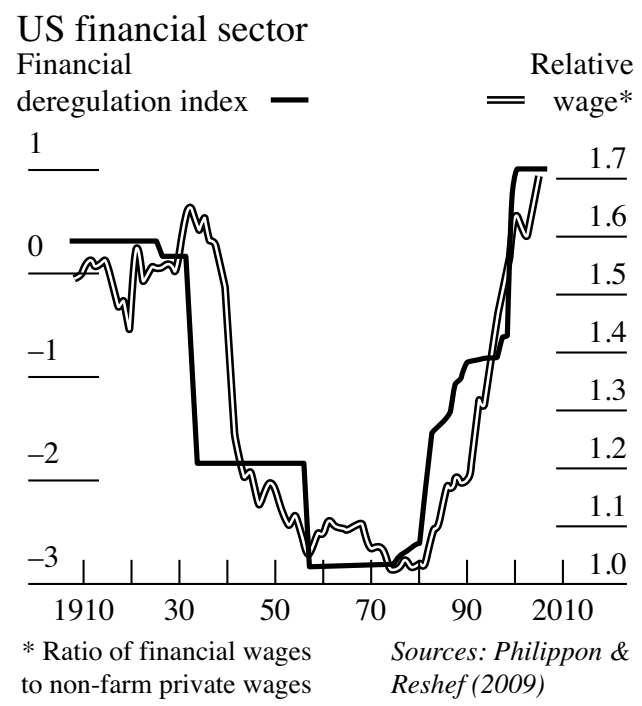

Figure 1.2 US financial wages compared to non-farm wages

patterns of pay of those who worked in the financial services sector in the United States during the twentieth century. From the starting point of the research in 1909, 'financial jobs were relatively skillintensive, complex, and highly paid until the 1930s and after the 1980 s, but not in the interim period'. The ratio of financial wages to non-farm private wages was dropping until about 1960 , but afterwards it grew sharply until by 2010 financial wages reached a peak that was 70 per cent higher than non-farm wages. We can infer from these figures that as long as the post-war surge in technology discussed by Kash was in effect (until close enough to Gordon's 'watershed' year), engineers were better paid than bankers, but afterwards bankers left engineers far behind. A similar pattern leading up to the earlier crash of 1929 is also visible (Philippon and Reschef 2009).

The evidence of the transition from technological to financial innovation is equally clear from the data for profits of firms. In the years immediately after World War II, when technology was still dominant, the financial sector in the US accounted for no more than 10-15 per cent of all corporate profits. At the peak of the recent boom, its peak surpassed 40 per cent (see Figure 1.3).

This pattern was repeated in other advanced countries, and is 


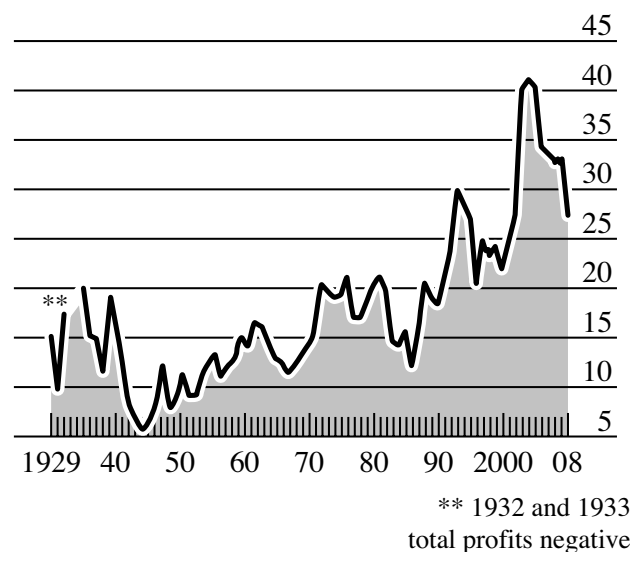

Figure 1.3 Financial sector percentage of US domestic corporate profits (based on Philippon and Reschef 2009)

particularly confirmed by the relative growth of financial assets in Britain. For almost a century, and as long as the country had a substantial manufacturing base, banking sector assets were about half the level of British GDP, but from about 1960, they began a steep climb to a level of more than five times GDP during the recent boom (Sheppard 2006 [1971]) supplemented by Bank of England data, and endorsed by the Bank's former governor, Mervyn King (2016: 95).

\section{FINANCIAL INNOVATION REPLACES TECHNOLOGY}

These figures, of course, reflect creative energy and brainpower following the money away from technology. The research shows how greatly rewards for employees who had the skills to devise and operate financial innovations were increased. This attracted talent and energy out of technology and other kinds of business into finance. The UK suffered more from this than other industrialized countries in Europe because the City of London is such an important centre for financial dealings, and thus provided an 
alternative outlet for money and talent. In terms of technological innovation, there can hardly be a more telling illustration than that of General Electric UK, the great conglomerate that had been built up by Arnold Weinstock from much of British engineering capacity. Towards the end of the Weinstock era, GE's main research laboratories at Wembley were only allowed to work on projects for which the start of returns could be foreseen within five years. This reflected the demand for short-term gains by the institutions that held most of GE's shares, but it meant that anything with a longer timescale than merely incremental innovation could not be contemplated.

Thus, these changes from technological to financial innovations signalled the end of capitalism. They are the cause of the enormous growth in inequality there has been over the past half-century. Hodgson (2015: 361) has stressed that 'the foremost generator of inequality under capitalism is not markets, but capital ... [which] is money or the realizable money value of owned and collateralizable value of property'. He points out that Piketty (2014) has 'provided rich historical data and empirical vindication of this claim, by showing how the main driver of inequality is the tendency of returns to capital to exceed the rate of economic growth'. For Piketty, the equation $r>g$, where $r$ is the rate of return on capital and $g$ is the rate of growth of the economy, 'sums up the overall logic of his conclusions' (2014: 25). He does indeed show how faster growth of return on capital compared with growth in the economy as a whole has led to extreme inequality.

However, such a divergence between growth rates is not inevitable, but a matter of property rights, which can work to bad or good ends. Returns to capital are a function of market power, so laws that increase market power on the one hand, and relaxation of discipline over the 'creation of money from nothing' on the other, could not fail to bring about growth in inequality. The shift towards financial innovation and away from technology also readily explains why productivity growth has slowed so drastically, and why in advanced countries members of the present generation are the first since the industrial revolution started that cannot look forward to a better future than their parents had been able to. They are also the reasons why progress towards the innovations that could deal with the threat of global warming has been so slow. Naomi Klein (2014) has documented her own progress from sceptic to agitator concerning this topic (the subtitle of her book is Capitalism vs. the Climate). Her 
work suggests that even in communications and information technology, where innovation remains strong in spite of the shift towards financial innovation, the emphasis has been wrong: much of the creative energy that has been deployed in information technology has led to nothing more than entertainment, at a time when a much more important challenge to the world is posed by the uncontrolled use of polluting fuels.

\section{CAPITALISM'S SELF-DESTRUCTION}

Capitalism was not destroyed by exogenous forces but from within itself, reflected in Schumpeter's observation that 'there is inherent in the capitalist system a tendency towards self-destruction' (1997 [1942]: 162). What is 'inherent' is self-interest in a property rights context that no longer has the power to force it to serve the public interest in following its own. Capitalism is therefore 'a complex, adaptive system which has reached the limits of its capacity to adapt' (Mason 2015: xiii).

This came about because capitalists gained control of the laws that underwrite property. How this happened will be the subject of Chapters 3 and 4, but it can only be fully understood against a background of knowledge of the origins of the essential components of capitalism, which are a set of values that give very high importance to individualism on the one hand, and private property rights on the other. It is to these, therefore, that attention will be turned next. 